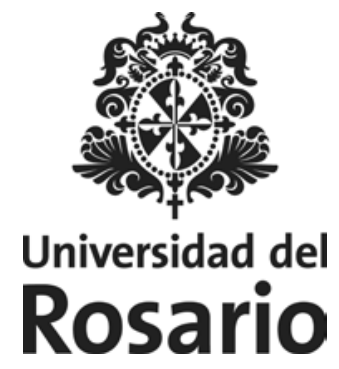





\section{Accompanied \\ Selfrehabilitation}




\section{Fergusson, Alberto}

Accompanied Selfrehabilitation / Alberto Fergusson. - Bogotá: El Rosario University Press. School of Medicine and Health Sciences, 2015.

xi, 103 pages. - (Medicine and Health Sciences Texts Collection)

ISBN: 978-958-738-611-0 (Paperback)

ISBN: 978-958-738-612-7 (Digital)

Psychiatry / Psychoanalysis / Mental Illness - Diagnosis and Treatment / Mental Illness - Rehabilitation / Colombia / Social politics/I Title

Source Catalog - El Rosario University. Library

amv

April 28,2015

Hecho el depósito legal que marca el Decreto 460 de 1995 


\title{
Accompanied Selfrehabilitation
}

\author{
Alberto Fergusson
}


Medicine and Health Sciences Texts Collection

(C) Editorial Universidad del Rosario

(C) Universidad del Rosario, Escuela de Medicina y Ciencias de la Salud

(C) Alberto Fergusson

(C) Courtenay M. Harding, Foreword

Editorial Universidad del Rosario

Cra. $7 \mathrm{~N}^{\circ} 12 \mathrm{~B}-41$ Of. 501

Tel: ++ 5712970200

editorial.urosario.edu.co
First Edition: Bogotá D.C., June, 2015

ISBN: 978-958-738-611-0 (Paperback)

ISBN: 978-958-738-612-7 (Digital)

Editorial coordination: El Rosario University Press Proofreader: Louise Watson

Translation and proofreader: David McPherson

Cover Desing: Miguel Ramírez, Kilka DG

Cover image: Anonymous, photographic archive of the Accompanied Selfrehabilitation Institute

Graphic design: Margoth de Olivos S.A.S.

Impression:

Printed and made in Colombia

Impreso y hecho en Colombia

All rigts reserved. No part of this publication may be reproduced without prior written permission from El Rosario University Press. 
Dedicated to Olivia, Diana, Pablo Emilio, Leopoldo, Ana María, Alicia y Emilio 



\section{Content}

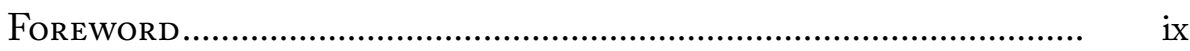

Prof. Courtenay M. Harding

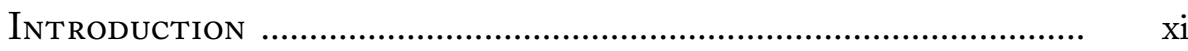

The Technique of Accompanied Autoanalysis and the

Theory of Psychosis as Psychological Destruction

and Decomposition

I

The Scientific Recovery of the Mind.

Accompanied Autoanalysis. An Empathic Approach

to Helping Deeply Disturbed Persons

Consent, Accountability and the Future of Therapeutic

Communities in the Light of Accompanied

Self-Rehabilitation: the Chemical Asylum and the Right

to be Socially Sanctioned

Alberto Fergusson in collaboration with Alba Realpe

Innovative Care for the Homeless Mentally Ill

in Bogotá, Colombia

Esperanza Diaz, Alberto Fergusson, and John S. Strauss

NoRmalcy Illuminated by Madness. $7 \mathrm{I}$

An Invitation to Self-Rehabilitation

84 



\section{Foreword}

Every once in a great while, there arises a young psychiatrist with entirely new rehabilitation ideas for helping patients retrieve their lives from psychosis. Usually such ideas initially elicit significant negative reactions from peers but a handful of sturdy physicians have continued on to show the world that something different is possible including George Brooks of the United States, E. E. Antinnen of Finland, and Franco Basaglia of Italy. Now we have to add to this list of illustrious doctors, the name of Alberto Fergusson of Colombia.

Dr. Fergusson also defied the establishment in the early 1980's. He found poor and homeless people with serious psychological problems who had been released from custodial hospitals and took them off the city streets and introduced them to a whole new way of life. Fergusson developed high quality facilities both in Bogotá and on a farm in a nearby town. He established housing facilities and a variety of possible job sites, such as a bakery, a pottery, and laundry as well as a library and a town meeting hall. This project followed the ideas of the Institute of Accompanied Self-Rehabilitation, also know as fungrata or "La Granja" (the farm), which he founded. For about 20 years, he worked to make it successful.

But like the pioneering rehabilitation psychiatrists before him, Fergusson kept observing what was needed and kept dreaming about what else might be possible. He decided that the "La Granja" experience was not good enough -that people were still not really part of the general community and not, in fact, managing their own lives. So he took a major step and let go of the need for control.

He began to help people find their own housing through entities serving the general public and jobs were secured through community resources as well. 
Fergusson, his clinical staff, and volunteers relegated themselves to supporting the efforts of patients as they worked toward recovery and tried to reclaim their lives. Therein lies the idea of Accompanied Self-Rehabilitation.

Fergusson openly shares what little scientific knowledge there is about the workings of the mind and psyche with individual biographies constructed targeting levels of functioning and psychosocial activities. Psychopathology is discussed only to discover what the triggers are and how to avoid escalating symptoms and unhelpful behaviors and cope better. Timing is different for each person. Dr. Fergusson assumes that people can ultimately be responsible for their own lives. Imagine that! He and his team of clinicians and volunteers actually walk side by side with people trading information and experiences - learning from one another in a mutually interactive, empathetic, and respectful manner. This represents a difference between acquired wisdom and knowledge gained from reading books.

The idea of stepping back to a supporting role is currently being discovered by general physicians who admit that only a few surgeries and antibiotics help to cure people. The new approach helps people learn to heal themselves by using changes in knowledge and life style choices to help resolve such diagnoses as type 2 Diabetes, high blood pressure, and many other disorders including schizophrenia. This job requires curiosity, persistence, optimism, encouragement, support, patience, kindness, and resilience on the part of the supporters as well as the person trying to recover. It also requires a strong dose of humility and a trust by the clinical team that most human beings might be able to learn to judge what is best for themselves and the timing involved. These findings are now being taught in a few medical schools and are slowly changing medical practice. Dr. Fergusson has been leading the way in psychiatry.

Courtenay M. Harding, Ph.D. Department of Psychiatry (retired) College of Physicians and Surgeons Columbia University, New York City March 9,2014 


\section{Introduction}

The technique of Accompanied Self-Rehabilitation and the theory of psychosis as a phenomenon of psychological destruction and decomposition are, in a certain sense, heirs to that wonderful dynamic that existed in the 1960s. Under the banner of two of its masters, Freud and Marx, otherwise officially declared dead, that generation allowed itself to dream and consider the possibility of a different kind of society, one in which human potential would be more fully developed. The Frankfurt School tried unsuccessfully to keep the two masters alive, but the evidence shows they had, in fact, in been buried alive. Their ideas have grown stronger, even though that has not been true of the movements they inspired.

Having had the chance to observe the phenomenon of psychosis for more than 40 years offers an unparalleled opportunity for insight into the human phenomenon. In this regard, this book merits the title Normalcy Illuminated by Madness. The mental mechanisms at work in the healthy and pathological minds are distressingly similar. This is why the technique of Accompanied SelfRehabilitation, initially used in cases of severe emotional disturbances, has proved so useful in accompanying all types of people along their various life paths. The theoretical inquiries that gave rise to the Accompanied Self-Rehabilitation Institute, together with the empirical evidence gathered-in other words, the experience of Fungrata - seemed to have led to the desired objective at the end of the 20th century. Repressive and asylum psychiatry appeared to be on the road to extinction. However, a new variant has emerged that we have termed the chemical asylum, in which the chemical molecules of drugs have replaced the former asylum bars. A new resolve, therefore, is needed to ensure that sufferers become the true leaders of their life processes, in the sense that Accompanied Self-Rehabilitation describes. 